\title{
Kelayakan finansial usaha pengolahan terasi udang rebon di kelurahan Bontang Kuala kota Bontang provinsi Kalimantan Timur
}

\author{
Financial feasibility of shrimp paste processing business in Bontang Kuala village, Bontang city, \\ East Kalimantan province \\ Muhammad Syafril $^{1)}$, Dayang Diah Fidhiani ${ }^{2)}$ \\ ${ }^{1}$ Fakultas Perikanan dan Ilmu Kelautan, Universitas Mulawarman Samarinda, Indonesia \\ ${ }^{2}$ Sekolah Tinggi Ilmu Perikanan, Malang, Indonesia \\ Email: msyafril@gmail.com
}

Informasi artikel: Dikirim: 06/03/2020 ditinjau: 06/03/2020 disetujui: $20 / 03 / 2020$

\section{(c) (i)}

Copyright (c) 2020

Muhammad Syafril,

Dayang Diah Fidhiani

\begin{abstract}
The objectives of this study are measure of financial feasibility of The shrimp paste processing business, and to know the marketing chain study was conducted in production centre of The shrimp paste, Bontang Kuala Village. Sampling using the census method. There were 7 shrimp paste producers in the study area Business feasibility of the financial aspect is measured by the analysis of discounted investment criteria; Net Present Value, Internal Rate of Return, Net Benefit Cost Ratio, Payback period), and analysis of non-discount investment criteria ; break-even point analysis and Return of Investment (ROI) analysis. Results showed that The shrimp paste processing business was financially feasible to be developed in the future, with NPV value were IDR. 32,667,112. IRR values respectively were $21 \%$, Net B/C values were 2.1 and Payback period values were 3.3 years. The actual condition of shrimp paste processing business, is above the break-even point condition for the aspect of sales and the production, Return of Investment (ROI) value were of $113.28 \%$. Marketing channel patterns that occur are level 0 channel patterns, ie from producers to consumers.

Keywords: Processing, shrimp paste, financial feasibility
\end{abstract}

\begin{abstract}
ABSTRAK: Usaha pengolahan terasi di kelurahan Bontang Kuala telah lama dikelola oleh masyarakat lokal sebagai mata pencaharian sampingan. Penelitian ini bertujuan 1) mengukur tingkat kelayakan usaha pengolahan terasi udang berdasarkan aspek finansial (keuangan), 2) mengetahui rantai pemasaran terasi udang. Penelitian ini dilakukan di sentra produksi terasi udang di kelurahan Bontang Kuala. Pengambilan sampel dilakukan dengan metode sensus. Terdapat 7 orang pengolah terasi udang di wilayah penelitian. Kelayakan usaha dari aspek finansial diukur dengan menggunakan analisis kriteria investasi terdiskonto yaitu nilai kiwari bersih (net present value), Tingkat pengembalian modal investasi (internal rate of return), Rasio manfaat bersih dengan biaya (net benefit cost ratio), masa pengembalian investasi (payback period), dan analisis kriteria investasi tidak terdiskonto, yang terdiri dari analisis titik impas (break event point) dan analisis return of investment (ROI). Hasil penelitian menunjukkan bahwa usaha pengolahan terasi udang layak secara finansial untuk dikembangkan di masa mendatang, dengan Nilai NPV Rp. 32.667.112,-. IRR $=21 \%$, Net B/C $=2,1$ dan payback period 3,3 tahun. Kondisi aktual usaha pengolahan terasi udang, berada di atas kondisi titik impas (break event point) bagi dari aspek jumlah penjualan dan jumlah hasil produksi, return of investment (ROI) usaha sebesar $113,28 \%$. Pola saluran pemasaran yang terjadi adalah pola saluran tingkat 0 yaitu dari produsen ke konsumen.
\end{abstract}

Kata Kunci : Pengolahan, terasi udang rebon, kelayakan finansial

Sitasi: Syafril, M., \& Fidhiani, D. D. (2020). Kelayakan finansial usaha pengolahan terasi udang rebon dikelurahan Bontang Kuala kota Bontang provinsi Kalimantan Timur. AGROMIX, 11(1), 33-48. https://doi.org/10.35891/agx.v11i1.1897 


\section{PENDAHULUAN}

Udang adalah salah satu komoditas ekspor komoditas perikanan yang berperan penting dalam pendapatan devisa Indonesia. Devisa yang diperoleh dari sektor perikanan sekitar $34 \%$ berasal dari ekspor udang. Produk udang yang diekspor dalam berbagai bentuk. Bentuk yang paling populer adalah olahan seperti udang beku, ini akan menghasilkan limbah udang sekitar $30 \%-75 \%$ dari berat udang. Meningkatnya jumlah limbah udang merupakan masalah yang perlu dicari untuk pemanfaatannya. Hal ini tidak hanya memberi nilai tambah bagi bisnis pengolahan udang, tetapi juga dapat mengatasi masalah pencemaran lingkungan yang ditimbulkan, terutama masalah bau dan estetika lingkungan yang tidak baik (Swastawati dkk., 2008).

Pengolahan dan konsumsi udang menghasilkan sejumlah besar limbah kulit udang yang kaya akan kitin dan protein (He dkk., 2020). Limbah kulit udang merupakan produk sampingan dari industri pengolahan udang. Sumber daya biomassa limbah kulit udang sebagian besar terdiri dari kitin (14$30 \%)$, protein $(40 \%)$, mineral (35\%) (Kannan dkk., 2017) dan apabila dibiarkan serta secara tidak tepat mulai membusuk, amina biogenik dengan bau menyengat yang kuat dapat dihasilkan, sehingga akan menimbulkan potensi ancaman terhadap lingkungan dan kesehatan manusia (Kandra dkk., 2012). Kitin merupakan senyawa penting dalam limbah kulit udang dan merupakan kelompok fungsional yang kaya akan kandungan N dan O (Crini, 2005; Tang dkk., 2012; Liang dkk., 2018).

Berbagai macam olahan yang berasal dari kekayaan hasil perikanan laut Indonesia seperti udang rebon dan ikan-ikan kecil yang dibuat menjadi terasi (Aristyan dkk., 2014; Rahmayati dkk., 2014). Terasi adalah udang atau ikan yang difermentasi atau campuran keduanya dengan garam. Ini biasa digunakan sebagai bahan memasak untuk membuat makanan lebih lezat (Gaffar, Umami dan Supardan, 2020). Olahan terasi yang disertai dengan pendampingan manajemen dan pemasaran, maka dapat meningkatkan pendapatan masyarakat (Dharma dkk., 2020).

Terasi udang merupakan satu di antara produk olahan perikanan dengan bahan baku utama udang rebon. Produk olahan ini dimanfaatkan oleh masyarakat sebagai bumbu penyedap makanan, khususnya bahan pembuatan sambal. Udang rebon yang merupakan bahan utama terasi, merupakan komoditi perikanan ekonomis penting yang masih diperoleh dari laut melalui usaha penangkapan oleh masyarakat nelayan. Jumlah udang rebon yang diperoleh nelayan relatif melimpah selama 10 bulan sepanjang tahun. Jumlah udang rebon yang melimpah, akan mengakibatkan terjadinya penurunan harga jual komoditi ini di tingkat produsen (nelayan). Upaya yang dilakukan nelayan dalam mengantisipasi hal ini, agar tidak berdampak 
buruk terhadap kinerja ekonomi usaha penangkapan, adalah melakukan usaha pengolahan udang rebon menjadi terasi, sehingga mampu menghasilkan nilai tambah ekonomi bagi keluarga nelayan.

Kota Bontang memiliki sentra produksi pengolahan terasi udang, yaitu kelurahan Bontang Kuala. Usaha pengolahan terasi di wilayah perdesaan pesisir ini telah cukup lama dikelola oleh masyarakat lokal sebagai mata pencaharian sampingan. Terdapat 10 orang pengolah terasi udang rebon yang masih aktif menjalankan usaha ini. Terdapat beberapa alasan yang menyebabkan pengolah terasi di wilayah masih bertahan menjalankan usaha ini, di antaranya adalah 1) Adanya ketersediaan udang rebon sepanjang tahun, 2) Supplier udang rebon adalah nelayan yang berdomisili di kota Bontang, umumnya adalah kepala keluarga dari pengolah terasi udang, 3) Usaha pengolahan terasi udang merupakan upaya pemanfaatan waktu luang oleh wanita nelayan untuk dapat meningkatkan pendapatan keluarga, 4) pengolah terasi udang telah memiliki skill khusus dalam pembuatan terasi, sehingga mampu menghasilkan terasi dengan kualitas baik, 5) terasi yang dihasilkan telah memiliki segmentasi pasar di dalam dan luar Kota Bontang, didukung oleh lembaga pemasaran yang aktif memasarkan produk olahan ini, 6) Bontang Kuala merupakan satu di antara destinasi wisata di Kota Bontang, dengan kekhasan oleh-olehnya berupa terasi udang, 7) adanya dukungan pemerintah pusat dan pemerintah daerah dalam upaya pengembangan usaha pengolahan terasi udang, yang merupakan satu di antara instrument pemerintah dalam penguatan ekonomi masyarakat nelayan dan peningkatan pendapatan nasional melalui sektor perikanan dan kelautan.

Data kelayakan usaha pengolahan terasi udang dari aspek finansial perlu disediakan melalui kegiatan penelitian oleh lembaga penelitian seperti perguruan tinggi. Data ini menjadi informasi awal bagi pihak manapun yang ingin mengetahui aktivitas usaha pengolahan terasi secara faktual.

\section{METODE PENELITIAN}

\section{Lokasi dan waktu penelitian}

Penelitian ini dilaksanakan di kelurahan Bontang Kuala Kota Bontang Provinsi Kalimantan Timur, pada tahun 2019. kelurahan Bontang Kuala merupakan sentra produksi terasi udang rebon di Kota Bontang, sehingga menjadi alasan utama dipilih sebagai lokasi penelitian, sehingga menyebabkan penelitian ini diarahkan pada studi kasus. Menurut Yin (2000), penelitian yang menggunakan pendekatan studi kasus memiliki 6 sumber utama data dan informasi yaitu dokumen (monografi wilayah, laporan pencatatan data wilayah secara gardual, hasil penelitian), rekaman arsip, wawancara, pengamatan 
langsung, observasi partisipan dan perangkatperangkat fisik.

\section{Jenis data dan metode pengumpulan data}

Penelitian ini menggunakan 2 jenis data yaitu data primer (data utama penelitian) dan data sekunder (data pendukung penelitian). Data primer diperoleh melalui observasi langsung ke lokasi penelitian dan wawancara dengan responden. Data primer meliputi Identitas responden, kinerja usaha (biaya produksi, jumlah produksi, harga jual produksi), rantai tata niaga, proses pengolahan terasi udang rebon, dan faktor pendorong dan penghambat usaha pengolahan terasi. Data sekunder merupakan data pendukung penelitian, yang diperoleh melalui tinjauan sumber-sumber kepustakaan yang berkaitan dengan tujuan penelitian. Data sekunder dalam penelitian ini meliputi monografi wilayah (kelurahan dan kota) yang diterbitkan oleh Pemerintah Kota Bontang, dan hasil-hasil penelitian yang sesuai dengan tujuan penelitian.

\section{Metode penarikan sampel}

Sampel penelitian adalah pengolah terasi udang di kelurahan Bontang Kuala. Terdapat 7 orang yang melakukan usaha pengolahan terasi udang di kelurahan Bontang Kuala. Dengan demikian jumlah sampel penelitian adalah 7 orang pengolah terasi udang rebon. Pengambilan sampel menggunakan metode sensus. Semua anggota populasi dijadikan sebagai anggota sampel. Sugiyono (2015) menyatakan bahwa, metode sensus disebut juga sebagai metode sampling jenuh yang termasuk ke dalam non probability sampling, yaitu pengambilan sampel dengan teknik ini memberikan peluang kepada semua anggota populasi untuk dipilih sebagai anggota sampel.

\section{Metode analisis data}

Analisis kelayakan finansial usaha pengolahan terasi menggunakan analisis kriteria investasi terdiskonto dan analisis non kriteria investasi. Kriteria investasi terdiskonto yang umum digunakan menurut Kadariah (2001) dan Gray dkk. (2002) yaitu Net present value (NPV) atau nilai kiwari bersih.

NPV adalah selisih antara manfaat (benefit) dengan biaya (cost) yang telah disesuaikan dengan nilai sekarang. Rumus yang digunakan adalah :

$$
\begin{aligned}
\mathrm{NPV}= & \sum_{t=1}^{t=n} \frac{B t}{(1+i)^{t}}-\sum_{t=1}^{t=n} \frac{C t}{(1+i)^{t}}= \\
& \frac{\sum_{t=1}^{n} B t-C t /(1+i)^{t}}{\sum_{t=1}^{n} B t-C t /(1+i)^{t}}
\end{aligned}
$$

\section{Keterangan}

Bt : benefit tahun ke $t$

Ct : biaya tahun ke $\mathrm{t}$

: discount rate

Jika : NPV>0, maka usaha pengolahan terasi udang rebon layak dilaksanakan $\mathrm{NPV}<0$, maka usaha pengolahan terasi udang rebon tidak layak dilaksanakan. 
Internal rate of return (IRR) atau tingkat pengembalian modal investasi

IRR menggambarkan earning power dari modal, yaitu kemampuan modal untuk menghasilkan keuntungan/net benefit. Jika IRR >opportunity cost of capital (OCC), maka usaha pengolahan terasi udang rebon layak dilaksanakan. Jika IRR <opportunity cost of capital (OCC), maka usaha pengolahan terasi udang rebon tidak layak dilaksanakan.

IRR $=\left(i_{2}-i_{1}\right)\left[\frac{N P V_{1}}{N P V_{1}-N P V_{2}}\right]$

\section{Net benefit cost ratio (Net $B / C$ )}

Net $B / C$ merupakan perbandingan antara benefit bersih dan biaya bersih dari tahuntahun yang berangkutan yang telah disesuaikan dengan nilai sekarang.

$$
\mathrm{NBCR}=\frac{\sum_{t=1}^{n} B t-C t /(1+i)^{t}}{\sum_{t=1}^{n} B t-C t /(1+i)^{t}}
$$

\section{Keterangan :}

Bt : Benefit terdiskonto pada tahun $\mathrm{t}$

Ct : Biaya terdiskonto pada tahun $\mathrm{t}$

i : Discount rate

Jika NBCR>1 maka usaha pengolahan terasi udang rebon layak dilaksanakan. Jika NBCR $<1$ maka, usaha pengolahan terasi udang rebon layak dilaksanakan.

\section{Payback periode atau masa pengembalian} investasi

Payback period berfungsi sebagai bahan pertimbangan yang membantu pengolah terasi untuk mengetahui masa waktu pengembalian biaya investasi yang telah dikeluarkan. Payback period merupakan satu di antara beberapa alat atau ukuran yang dapat dipakai sebagai dasar pengambilan keputusan untuk melakukan investasi (Djamin, 1992).

$$
P B P=T_{p^{-1}}+\frac{\sum_{i=1}^{n} \bar{I}_{i}-\sum_{i=t}^{n} \bar{B}_{i e p-1}}{\bar{B}_{p}}
$$

Analisis non kriteria investasi yang digunakan dalam menilai kelayakan usaha pengolahan terasi udang rebon adalah analisis titik impas (break event point) dan Return of Investment (ROI). Analisis titik impas terbagi menjadi 2 aspek yaitu jumlah penjualan dan jumlah hasil produksi.

\section{Analisis penjualan pada titik impas}

Analisis titik impas bertujuan untuk mengukur hubungan dari volume produksi, volume penjualan, harga jual produk, biaya produksi, penerimaan dan laba atau rugi. Analisis titik impas membutuhkan dukungan dari laporan rugi laba (Jumingan, 2006). Halim (2011) menyatakan bahwa analisis titik impas dapat dibagi menjadi 2 yaitu titik impas dalam satuan penjualan dan titik impas dalam satuan unit produksi (jumlah produksi). Penjualan pada titik impas adalah hasil penjualan yang diperoleh oleh perusahaan mampu menutupi biaya operasional yang telah dikeluarkan oleh perusahaan tersebut:

$\mathrm{BEP}=\mathrm{TFC} /\{1-(\mathrm{TVC} /$ Penjualan $)\}$

Keterangan :

TFC : Jumlah Biaya Tetap (Total Fixed Cost) 
TVC : Jumlah Biaya Tidak Tetap (Total Variable Cost)

\section{Analisis jumlah produksi pada titik impas}

Merupakan jumlah hasil produksi yang mampu menutupi seluruh biaya operasional yang telah dikeluarkan oleh perusahaan:

BEP Produksi $(\mathrm{kg})=\mathrm{TC} / \mathrm{P}$

Keterangan :

$\mathrm{TC}=$ Total Cost atau Jumlah Biaya $\left(\right.$ Rpbln $\left.^{-1}\right)$

$\mathrm{P} \quad=$ Harga jual $\left(\mathrm{Rp} \mathrm{kg}^{-1}\right)$

\section{Analisis return of investment (ROI)}

Analisis ROI merupakan analisis yang bertujuan untuk mengetahui kemampuan modal investasi dalam bentuk keseluruhan aktiva usaha untuk menghasilkan keuntungan pada suatu periode tertentu (Gigentika, dkk. 2013).

$R O I=\frac{\sum \text { Laba Bersih }}{\sum \text { Modal Investasi }} \times 100 \%$

ROI merupakan parameter untuk mengetahui tingkat pengembalian investasi dari benefit (penerimaan) yang diterima pemilik. Kegiatan perikanan layak dikembangkan bila mempunyai nilai $\mathrm{ROI}>1$ (100\%) (Fauzi, dkk., 2011).

\section{HASIL DAN PEMBAHASAN}

\section{Profil usaha}

Usaha pengolahan terasi merupakan usaha turun-temurun yang dilakukan oleh masyarakat pesisir Bontang Kuala. Usaha ini sudah ada sejak puluhan tahun yang lalu, sejak berdirinya Kampung Bontang Kuala oleh masyarakat pendatang dari Sulawesi maupun masyarakat lokalnya. Jumlah masyarakat lokal yang menjadi pengolah terasi di wilayah ini adalah 7 orang. Pengetahuan dan keterampilan dalam mengolah terasi udang ini diperoleh dari keluarga, kerabat, teman-teman satu profesi maupun dari media surat kabar, media elektronik dan penyuluhan yang dilakukan oleh pemerintah daerah dalam hal ini Dinas Ketahanan Pangan, Perikanan dan Pertanian Kota Bontang.

Usaha pengolahan terasi ini dilakukan secara individu oleh masyarakat, dan tidak tergabung dalam satu kelompok usaha bersama (KUB) bidang perikanan, sebagaimana usaha perikanan tangkap dan budi daya. Hal ini dikarenakan :

1. Usaha pengolahan terasi masih berada pada skala subsisten, hanya bertujuan untuk memenuhi permintaan lokal Kota Bontang dan sekitarnya. Produk terasi yang dihasilkan cenderung dijadikan sebagai produk oleh-oleh untuk mendukung kegiatan wisata bahari di Bontang Kuala.

2. Pengolah terasi udang rebon belum termotivasi untuk mengembangkan usaha melalui peningkatan skala usaha, baik secara individu maupun secara berkelompok.

3. Pengolah terasi udang rebon adalah ibu rumah tangga nelayan, yang memiliki kegiatan domestik rumah tangga. Pekerjaan sebagai pengolah hanyalah pekerjaan 
sampingan untuk memanfaatkan waktu luang, memanfaatkan udang rebon sebagai hasil tangkapan nelayan dan memperkuat ekonomi keluarga.

Produk terasi udang yang dihasilkan oleh pengolah di kelurahan Bontang Kuala memiliki 3 bentuk atau pola yaitu bentuk bulat kecil, bulat besar dan segi empat. Harga jual terasi udang bentuk bulat besar rata-rata Rp.16.429 per bungkus (satu bungkus isi 8), bentuk bulat kecil Rp.4.286 per bungkus, dan bentuk segi empat Rp.9.286 per bungkus. Pembukuan usaha yang digunakan oleh pengolah masih bersifat sederhana. Kegiatan transaksi, hanya tercatat pada buku yang disertai dengan nota pembelian atau penjualan. Pembukuan usaha belum menggunakan model pembukuan yang sederhana, informatif dan mudah dilakukan.

Kegiatan pembuatan atau pengolahan terasi udang dilakukan di rumah dengan memanfaatkan sarana prasarana rumah tangga yang dimiliki seperti air bersih, listrik, dan kompor gas. Bahan baku utama berupa udang rebon diperoleh pelaku usaha dari nelayan lokal yang berdomisili di kelurahan Bontang Kuala.
Harga udang rebon hasil tangkapan nelayan ini berkisar Rp.30.000,- sampai dengan Rp.35.000 per kg.

\section{Aspek finansial usaha pengolahan terasi}

\section{Biaya investasi}

Biaya investasi pada usaha pengolahan terasi merupakan biaya yang harus dikeluarkan oleh pengolah terasi udang rebon untuk memulai usaha pengolahan. Rata-rata jumlah biaya investasi yang dikelola oleh sebesar sebesar Rp. 1.988.143,. Biaya investasi usaha pengolahan terasi bersumber dari modal sendiri dan pinjaman keuangan dari kerabat. Pengolah terasi di wilayah ini belum termotivasi untuk melakukan pinjaman modal usaha ke bank. Mereka memiliki pemikiran bahwa penerimaan usaha ini belum mampu membayar cicilan kredit modal usaha tersebut. Berdasarkan data BPS Kota Bontang Tahun 2018, dapat diketahui bahwa, terdapat beberapa skim kredit usaha perikanan yang disediakan oleh pihak perbankan di kota Bontang, seperti Kredit Usaha Rakyat (KUR). Kebutuhan biaya investasi secara rinci ditampilkan pada tabel di bawah ini.

Tabel 1. Rekapitulasi biaya investasi pada usaha pengolahan terasi udang rebon

\begin{tabular}{|c|c|c|c|c|c|c|c|c|c|}
\hline No & Investasi & $\begin{array}{c}\text { Jumlah } \\
\text { (unit) }\end{array}$ & $\begin{array}{c}\text { Harga } \\
\left.\text { (Rp unit }^{-1}\right)\end{array}$ & $\begin{array}{l}\text { Jumlah Harga } \\
\text { (Rp) }\end{array}$ & $\begin{array}{l}\text { Umur } \\
\text { Teknis } \\
\text { (tahun) }\end{array}$ & $\begin{array}{l}\text { Nilai Sisa } \\
\quad \text { (Rp) }\end{array}$ & $\begin{array}{l}\text { Depresiasi } \\
\text { (Rp siklus- }{ }^{1} \text { ) }\end{array}$ & $\begin{array}{l}\text { Depresiasi } \\
\left(\text { Rp bln }^{-1}\right)\end{array}$ & $\begin{array}{l}\text { Depresiasi } \\
\left(\mathrm{Rp} \mathrm{thn}^{-1}\right)\end{array}$ \\
\hline 1 & Lesung & 1 & 92.143 & 92.143 & 5 & 0 & 4.374 & 8.748 & 21.286 \\
\hline 2 & Alu & 1 & 57.143 & 57.143 & 5 & 0 & 2.642 & 5.284 & 12.857 \\
\hline 3 & Cetakan & 3 & 22.143 & 62.143 & 3 & 0 & 2.290 & 4.579 & 18.571 \\
\hline 4 & Tempat Jemur & 4 & 69.143 & 230.571 & 1 & 0 & 9.476 & 18.951 & 230.571 \\
\hline 5 & Ember & 3 & 27.143 & 67.714 & 1 & 0 & 2.783 & 5.566 & 135.429 \\
\hline 6 & Baskom & 2 & 26.857 & 57.714 & 1 & 0 & 2.372 & 4.744 & 115.429 \\
\hline 7 & Tampi & 2 & 27.143 & 38.571 & 1 & 0 & 1.585 & 4.744 & 115.429 \\
\hline 8 & Telepon (HP) & 1 & 832.143 & 832.143 & 3 & 83.214 & 215.445 & 61.556 & 249.643 \\
\hline 9 & Kompor Gas & 1 & 300.000 & 300.000 & 5 & - & 10.274 & 20.548 & 50.000 \\
\hline \multirow[t]{2}{*}{10} & Tabung Gas & 1 & 250.000 & 250.000 & 5 & - & 12.329 & 24.658 & 60.000 \\
\hline & \multicolumn{3}{|c|}{ Jumlah } & 1.988 .143 & & & 263.568 & 159.376 & 1.009 .214 \\
\hline
\end{tabular}

Sumber : Data primer diolah (2019) 


\section{Biaya operasional}

Biaya operasional merupakan biaya yang harus dikeluarkan oleh pengolah terasi pada saat proses produksi berlangsung. Biaya operasional sering juga diistilahkan sebagai modal kerja. Proses produksi terasi udang berlangsung selama 5 hari sampai 8 hari, dimulai dari kegiatan penyiapan bahan dan alat hingga kegiatan pengemasan dan penjualan. tabel berikut:

Tabel 2. Rekapitulasi rata-rata biaya operasional usaha pengolahan terasi

\begin{tabular}{|c|c|c|c|c|c|c|c|}
\hline \multirow[b]{2}{*}{ No } & \multirow{2}{*}{ Biaya Operasional } & \multirow{2}{*}{ Satuan } & \multirow{2}{*}{$\begin{array}{l}\text { Jumlah } \\
\text { unit }\end{array}$} & \multirow{2}{*}{$\begin{array}{c}\text { Harga } \\
\text { Rp unit }^{-1}\end{array}$} & \multicolumn{2}{|c|}{ Jumlah Harga } & \multirow{2}{*}{$\begin{array}{c}\text { Kontribusi (\%) } \\
\text { Rp siklus }^{-1}\end{array}$} \\
\hline & & & & & Rp siklus $^{-1}$ & Rp bulan $^{-1}$ & \\
\hline$A$ & Biaya Variabel & & & & & & \\
\hline 1 & Upah TK & Orang & 1 & 93.000 & 104.571 & 209.143 & 27,10 \\
\hline 2 & Udang Rebon & $\mathrm{Kg}$ & 4 & 32.857 & 127.857 & 255.714 & 33,14 \\
\hline 3 & Garam & Unit & 1 & 4.786 & 5.714 & 11.429 & 1,48 \\
\hline 4 & Air Bersih & Unit & 1 & 24.643 & 24.643 & 49.286 & 6,39 \\
\hline 5 & Plastik & Unit & 2 & 3.786 & 5.000 & 10.000 & 1,30 \\
\hline \multirow[t]{2}{*}{6} & Label & Lembar & 7.165 & 1.821 & 6.464 & 12.929 & 1,68 \\
\hline & Sub Jumlah A & & & & 274.250 & 548.500 & 71,08 \\
\hline B & Biaya Tetap & & & & & & - \\
\hline 7 & Pulsa & Unit & 1 & 50.000 & 50.000 & 100.000 & 12,96 \\
\hline \multirow[t]{3}{*}{8} & Depresiasi & Unit & 1 & & 61.559 & 123.117 & 15,96 \\
\hline & Sub Jumlah B & & & & 111.559 & 223.117 & 28,92 \\
\hline & Jumlah Total & & & & 385.809 & 771.617 & 100,00 \\
\hline
\end{tabular}

Sumber : Data primer diolah (2019)

Produksi, penerimaan dan keuntungan usaha

Kondisi usaha pengolahan terasi udang masih berada pada skala subsisten, namun demikian, para pelaku usaha ini tetap memiliki tujuan ekonomi yang ingin dicapai yaitu menghasilkan keuntungan maksimum melalui efisiensi biaya produksi. Rata-rata jumlah produksi terasi setiap bulan sebesar 49 bungkus untuk terasi bulat besar $(6,14 \mathrm{~kg}), 19$ bungkus

Dalam satu bulan terjadi 2 kali proses produksi, dengan demikian satu siklus produksi berlangsung selama 5 sampai dengan 8 hari. Jumlah biaya operasional persiklus produksi sebesar Rp.385.809 atau Rp.771.617 per bulan, dengan komponen biaya terbesar adalah biaya pembelian udang rebon (33,14\%). Rekapitulasi rata-rata biaya operasional ditampilkan pada 
Tabel 3. Laporan rugi laba usaha pengolahan terasi udang rebon persiklus produksi (14 hari) dalam rupiah

\section{Usaha pengolahan terasi udang di Bontang Kuala}

Laporan rugi laba per 14 hari

\begin{tabular}{lr} 
Penerimaan dari Penjualan Terasi Udang rebon & 550.714 \\
Biaya Operasional : & \\
Biaya Variabel & 274.250 \\
Biaya Tetap & 111.559 \\
Jumlah Biaya Operasional & 385.809 \\
Laba Bersih Operasional & 164.905 \\
Pendapatan di luar Operasional & - \\
Pendapatan dari Bunga & - \\
Pendapatan dari Sewa & - \\
\hline Laba Bersih & - \\
\hline
\end{tabular}

Sumber : Data primer diolah (2019)

Tabel 4. Laporan rugi laba usaha pengolahan terasi di Bontang Kuala

\section{Usaha pengolahan terasi udang di Bontang Kuala}

Laporan rugi laba per bulan dalam rupiah

\begin{tabular}{lr} 
Penerimaan dari Penjualan Terasi Udang & 1.101 .429 \\
Biaya Operasional & \\
Biaya Variabel & 548.500 \\
Biaya Tetap & 223.117 \\
Jumlah Biaya Operasional & 771.617 \\
Laba Bersih Operasional & 329.811 \\
Pendapatan di luar Operasional & - \\
Pendapatan dari Bunga & - \\
Pendapatan dari Sewa & - \\
\hline
\end{tabular}

Laba Bersih

329.812

Sumber : Data primer diolah (2019)

Analisis kelayakan finansial dengan kriteria

memenuhi kriteria investasi yang telah disusun

\section{investasi terdiskonto}

Analisis ini dihitung dengan menggunakan proyeksi arus kas (cash flow) rugi laba. Proyeksi arus kas dalam perhitungan kriteria investasi berperan penting dalam menganalisis kelayakan suatu usaha dari aspek keuangan (finansial). Analisis finansial dengan menggunakan metode kriteria investasi terdiskonto (discounted measures), meliputi Net Present Value (NPV). Internal Rate of Return (IRR), Net Benefit Cost Ratio (NBCR), dan Payback period (PP). Usaha dikatakan layak apabila mampu secara teoritis. Adapun deskripsi masingmasing metode kriteria investasi yang digunakan dalam analisis usaha pengolahan terasi udang di kelurahan Bontang Kuala Kota Bontang, dijelaskan sebagai berikut :

\section{Net present value (NPV)}

Keuntungan usaha pengolahan terasi udang rebon yang akan diperoleh di masa 5 tahun mendatang haruslah dikonversikan ke nilai sekarang dalam bentuk present value of money. NPV merupakan selisih antara present value dari benefit (kas masuk) dan pesent value 
dari biaya (kas keluar). Berdasarkan hasil perhitungan, diperoleh NPV sebesar Rp.32.667.112,- untuk masa produksi sepanjang tahun. Dengan demikian, usaha pengolahan terasi udang rebon yang dikelola oleh pengolah di kelurahan Bontang Kuala Kota Bontang secara finansial layak untuk dilaksanakan.

\section{Internal rate of return (IRR)}

IRR merupakan nilai discount rate i (tingkat suku bunga) yang membuat NPV dari dari usaha pengolahan terasi udang rebonsama dengan 0 (nol). IRR dapat juga dianggap sebagai tingkat keuntungan atas investasi bersih dari usaha pengolahan ini, jika setiap benefit bersih yang dihasilkan oleh usaha ini diinvestasikan kembali pada tahun berikutnya dan mendapatkan tingkat keuntungan yang sama selama sisa umur usaha. Hasil perhitungan menunjukkan bahwa, nilai IRR sebesar $21 \%$ dengan masa produksi 10 bulan dalam satu tahun. Angka tersebut lebih besar jika dibandingkan dengan nilai OCC 5\% (penentuan OCC didasarkan pada bunga deposito BRI Kota Bontang). Berdasarkan nilai IRR, dapat dinyatakan bahwa usaha ini layak untuk dilaksanakan dan dikembangkan di masa-masa mendatang.

\section{Net benefit cost ratio (NBCR)}

Semua aliran biaya $($ cost $=\mathrm{C})$ dan manfaat (benefit = B) yang terjadi pada usaha pengolahan terasi udang rebon di kelurahan Bontang Kuala, selama umur usaha 5 tahun, akan diukur dengan nilai uang sekarang, melalui teknik perhitungan discount factor, dengan nilai OCC 5\%. Usaha pengolahan terasi udang rebon menghasilkan nilai Net B/C sebesar 2,1 > 1 . Hal ini menunjukkan modal investasi yang telah digunakan dalam menjalankan usaha pengolahan ini mampu menghasilkan benefit bersih, dengan nilai efek pengganda 2,1. Dengan demikian usaha pengolahan terasi udang rebon layak untuk dilaksanakan.

\section{Payback period}

Pelaku usaha pengolahan terasi udang rebon, telah membayar biaya investasi untuk pembelian berbagai peralatan utama dan pendukung pengolahan terasi. Biaya investasi ini merupakan korbanan ekonomi yang wajib dilaksanakan oleh pengolah, dan harus segera dikembalikan dalam bentuk penerimaan dan keuntungan usaha (benefit bersih), agar dapat dilakukan reinvestasi dan penguatan diversifikasi usaha di bidang lain. Dengan Demikian diperoleh akumulasi profit maksimum yang berdampak pada akselerasi penguatan perekonomian keluarga dan regional.

Analisis finansial menunjukkan bahwa, korbanan biaya investasi pada usaha pengolahan terasi akan mampu dikembalikan pada tahun ke 3 bulan ke 4 (3,3 tahun). Masa pengembalian yang lebih cepat, akan memberikan peluang kepada pengolah terasi udang rebon untuk memperoleh present value 
dari akumulasi net benefit (keuntungan) masa mendatang. Rekapitulasi analisis semaksimal mungkin. Berdasarkan kriteria keuangan (finansial) usaha pengolahan terasi investasi ini, maka usaha pengolahan terasi udang rebon di kelurahan Bontang Kuala yang dikelola oleh masyarakat pesisir Bontang ditampilkan pada tabel berikut. Kuala layak dilaksanakan dan dikembangkan di

Tabel 5. Hasil analisis finansial usaha pengolahan terasi udang rebon di kelurahan Bontang Kuala Kota Bontang

\begin{tabular}{llcl}
\hline No & \multicolumn{1}{c}{ Kriteria Kelayakan } & Nilai & \multicolumn{1}{c}{ Justifikasi Kelayakan } \\
\hline 1 & NPV (Rp) & $32.667 .112,-$ & NPV > 0 : Layak \\
2 & IRR (\%) & 21 & IRR $>15 \%$ (suku bunga kredit): Layak \\
3 & Net B/C & 2,1 & Net B/C $>1$ : Layak \\
4 & Payback periode (thn) & 3,3 & Payback period< Umur Usaha : Layak \\
\hline
\end{tabular}

Sumber : Data primer diolah (2019)

\section{Analisis titik impas}

Usaha pengolahan terasi yang dikelola oleh masyarakat lokal di kelurahan Bontang Kuala, memiliki titik impas usaha pada setiap tahun, berdasarkan aspek harga jual produk, Tabel 6. Arus kas rugi laba usaha pengolahan terasi

\begin{tabular}{|c|c|c|c|c|c|}
\hline \multirow{2}{*}{ Uraian } & \multicolumn{5}{|c|}{ Tahun Ke } \\
\hline & 1 & 2 & 3 & 4 & 5 \\
\hline \multicolumn{6}{|l|}{ Penerimaan } \\
\hline Jumlah Produksi (kg) & 749 & 749 & 749 & 749 & 749 \\
\hline Total Penjualan (Rp) & 12.298 .280 & 12.298 .280 & 12.298 .280 & 12.298 .280 & 12.298 .280 \\
\hline Total Pengeluaran (Rp) & 7.334.786 & 7.334 .786 & 7.334 .786 & 7.334 .786 & 7.334 .786 \\
\hline Rugi/Laba & 4.963 .494 & 4.963 .494 & 4.963 .494 & 4.963 .494 & 4.963 .494 \\
\hline \multicolumn{6}{|l|}{ Titik Impas (BEP): } \\
\hline Penjualan (Rp) & 1.805 .045 & 1.805 .045 & 1.805 .045 & 1.805 .045 & 1.805 .045 \\
\hline Produksi (Kg) & 395 & 395 & 395 & 395 & 395 \\
\hline
\end{tabular}

Sumber : Data primer diolah (2019)

Tabel di atas memberikan penafsiran bahwa usaha pengolahan terasi udang menghasilkan keuntungan atau laba bersih per tahun sebesar Rp. 4.963.494 dan Rp. 4.218.970. Kondisi aktual usaha berdasarkan aspek penjualan dan jumlah produksi berada di atas kondisi titik impas (break event point), dengan demikian berdasarkan analisis usaha non biaya produksi dan penjualan. Analisis titik impas dihitung dengan menggunakan arus kas rugi laba usaha, sebagaimana ditampilkan di bawah ini. 
memberikan penafsiran bahwa, biaya investasi yang telah dikeluarkan oleh pengolah, mampu menghasilkan keuntungan usaha (laba bersih) sebesar $113,28 \%$. Keuntungan usaha ini lebih besar dibandingkan dengan suku bunga deposito BRI 5\% pada tahun 2019. Dengan demikian usaha pengolahan terasi udang rebon layak untuk dijalankan.

Usaha pengolahan terasi udang yang telah lama dikelola oleh masyarakat di wilayah kelurahan Bontang Kuala, memiliki prospek yang baik untuk dikembangkan sebagai mata pencaharian utama bagi masyarakat lokal. Usaha ini mampu memberikan benefit ekonomi yang dimanfaatkan sebagai instrument penguatan ekonomi masyarakat pesisir. Hal ini sesuai dengan hasil penelitian dari Nugraha (2017) tentang Analisis Kelayakan Finansial Usaha Terasi Sijuk di Desa Sungai Padang Kecamatan Sijuk Kabupaten Belitung. Hasil penelitian yang dilakukan menunjukkan bahwa usaha terasi sijuk memberikan keuntungan karena memiliki nilai profit sebesar Rp.17.558.914,29/tahun, nilai gross profit ratio sebesar $50,61 \%$, rate of return per capital investment sebesar 1,02, dan return on investmen sebesar $74,58 \%$. Usaha terasi sijuk layak dilanjutkan karena memiliki nilai dicounted payback period sebesar 1,34 tahun, nilai net present value sebesar Rp.53.801.240,49, nilai internal rate of return sebesar 53 persen, dan nilai profitability index sebesar 3,29. Dari hasil analisis switching value disimpulkan bahwa usaha terasi sijuk layak dilanjutkan karena persentase kenaikan maksimum biaya operasional yang masih dapat ditolerir adalah sebesar $80,69 \%$ dan persentase penurunan maksimum harga jual produk terasi sijuk yang masih dapat ditolerir adalah sebesar 27,68\%. Rekomendasi yang diberikan oleh penelitian bahwa a). Pelaku usaha terasi di Desa Sungai Padang dapat mengembangkan usahanya dengan menambah jumlah bahan baku usaha terasi sijuk yaitu udang rebon dengan cara mendatangkan bahan baku dari luar Desa Sungai Padang, b). Campur tangan pemerintah diperlukan untuk pengembangan usaha terasi sijuk di Desa Sungai Padang yaitu dengan cara memperluas pasar dari produk terasi sijuk seperti mengadakan pameran, serta memberikan bantuan sarana produksi bagi pelaku usaha terasi sijuk.

Hasil penelitian yang dilakukan oleh Mustofa dan Ainiyah (2018) tentang Analisis Usaha Terasi Udang di Desa Tambaklekok Kabupaten Pasuruan menunjukkan bahwa usaha terasi yang dikelola oleh masyarakat lokal di wilayah penelitian tidak layak secara finansial, karena usaha ini menghasilkan kerugian bagi pelaku usahanya. Hal ini ditunjukkan oleh nilai $\mathrm{B} / \mathrm{C}$ ratio $<1$ yaitu 0,82 , namun jika berdasarkan kriteria $\mathrm{R} / \mathrm{C}$, maka usaha ini menguntungkan dan layak untuk dilaksanakan karena memberikan nilai R/C sebesar $1,82(R / C>1)$. Peneliti memberikan saran a) Pemilik usaha terasi di Desa 
Tambaklekok diharapkan menambah keterampilan dalam hal produksi, misal dengan menggunakan mesin penggiling dan sebagainya, b) Diharapkan dapat meningkatkan hasil produksi dengan menambah jumlah bahan baku agar dapat menambah penerimaan serta pendapatan dan usaha layak untuk dijalankan, c) 3. Melakukan kegiatan promosi agar menambah luas pasar atau peluang serta mengajukan perizinan usaha terhadap pemerintah agar menjamin produk yang dihasilkan, d) Untuk menghasilkan produk terasi udang dengan kualitas baik di tempat pembuatan terasi Desa Tambaklekok, maka bahan dan peralatan yang digunakan juga harus baik, dan sesuai persyaratan keamanan pangan agar lebih terjamin mutu produk, e) Diharapkan ada penelitian lebih lanjut tentang analisis usaha terasi di Desa Tambaklekok ditinjau dari berbagai aspek yang lebih terpadu.

\section{Saluran pemasaran}

Pemasaran secara umum dianggap sebagai proses aliran barang. Saluran pemasaran pengolah terasi di Bontang Kuala adalah:

\section{Pola nol tingkat: produsen $\rightarrow$ konsumen}

Saluran non tingkat (saluran pemasaran langsung) terdiri seorang produsen yang langsung ke konsumen (Kotler, 2002). Pola pada saluran nol tingkat, merupakan saluran pemasaran yang paling pendek, yaitu produsen langsung menjual ke konsumen tanpa melalui lembaga pemasaran. Pola ini berlangsung dengan cara konsumen datang langsung membeli ke produsen, di antaranya konsumen rumah tangga, pemilik rumah makan Jimbaran, Rumah makan Gami Cobek, rumah makan Batavia, pemilik Kios sekitar Objek Wisata Bontang Kuala. Pengertian konsumen dapat dibagi sebanyak 3 (tiga) macam yakni : a). Konsumen secara umum adalah setiap orang yang mendapatkan barang atau jasa digunakan untuk tujuan tertentu; b). Konsumen antara adalah setiap orang yang mendapatkan barang dan/jasa untuk digunakan dengan tujuan membuat barang/jasa lain atau untuk diperdagangkan (tujuan komersial); c). Konsumen akhir adalah setiap orang alami yang mendapat dan menggunakan barang dan/atau jasa untuk tujuan memenuhi kebutuhan hidupnya pribadi, keluarga dan atau rumah tangga dan tidak untuk diperdagangkan kembali (non komersial) (Nasution, 1999).

\section{Faktor penghambat usaha}

1. Ketersediaan bahan baku utama terasi yaitu udang rebon tidak terjadi sepanjang tahun, sehingga pengolah terasi tidak melakukan kegiatan pengolahan selama 2 bulan yaitu bulan mei dan juni. Padahal tingkat permintaan terasi udang dari Kota Bontang cukup tinggi setiap tahunnya.

2. Belum adanya fasilitas penjemuran yang dapat digunakan pada saat musim hujan. Kegiatan penjemuran terasi udang masih dilakukan secara tradisional, dengan melakukan penjemuran terasi di teras rumah 
pada saat terik matahari, dan jika hujan turun, pengolah akan menutup terasi tersebut dengan terpal. Hal ini menjadi kurang efisien dan menjadi ancaman terjadinya penurunan kualitas terasi, bahkan terasi menjadi busuk. Biaya produksi yang telah dikorbankan oleh pengolah, tidak bisa kembali, dan akan menjadi kerugian usaha.

3. Terjadinya over produksi terasi udang pada bulan-bulan tertentu, dikarenakan adanya ketersediaan udang rebon yang melimpah dari nelayan lokal, dengan harga yang murah. Pengolah akan melakukan pembelian udang rebon dalam jumlah besar dan melakukan produksi terasi udang dengan jumlah yang besar pula.

4. Upaya pemasaran produk terasi udang secara massal, dengan volume pemasaran yang tinggi, belum mampu dilakukan secara maksimal di luar Kota Bontang, sehingga jika terjadi kelebihan produksi sebagaimana pada poin c, harga jual terasi udang di tingkat pengolah akan mengalami penurunan. Pengolah hanya mampu memasarkan terasi yang dihasilkan di wilayah Bontang Kuala saja, dengan jumlah calon konsumen yang sangat terbatas.

5. Belum adanya kelompok pengolah terasi udang di wilayah ini. Kelompok pengolah dapat berperan dalam meningkatkan kinerja ekonomi usaha dan mengembangkan usaha ini melalui kemitraan dengan pihak lain seperti pedagang, pemilik modal, perbankan, perusahaan dan pemerintah.

Upaya mengatasi pemasalahan usaha pengolahan terasi, khususnya dalam hal penyediaan sarana prasarana produksi dapat dilakukan melalui pembiayaan oleh pihak lain seperti lembaga bank dan pemerintah. Usaha perikanan rakyat di Kota Bontang, memiliki peluang besar untuk memperoleh pembiayaan usaha dari pihak bank pemerintah (BRI, BNI, Bank Syariah Mandiri, Bank Mandiri, BankKaltim) dan bank swasta (BCA, BPR Dana Artha), pembiayaan dari lembaga non bank (BMT Mitra Amanah, KJKS Halal, PKBL dari PT PKT, Pedagang Pengumpul). Setiap lembaga keuangan bank dan non bank memiliki skema pembiayaan tersendiri, dan telah disesuaikan dengan karakteristik usaha perikanan rakyat di Bontang (Syafril dkk., 2016).

\section{KESIMPULAN}

Usaha pengolahan terasi yang dilakukan oleh masyarakat lokal kelurahan Bontang Kuala memiliki prospek yang baik untuk dikembangkan di masa mendatang. Usaha ini layak secara finansial dengan nilai NPV $=R p$. 32.667.112,-. IRR $=21 \%$, Net $B / C=2,1$ dan payback period 3,3 tahun. Usaha pengolahan terasi mampu menghasilkan laba bersih sebesar Rp.4.218.970. Kondisi aktual dari usaha pengolahan ini berada di atas kondisi titik impas (break event point) bagi dari aspek penjualan, dan jumlah produksi, nilai ROI 
sebesar $113,28 \%$. Pola saluran pemasaran yang terjadi adalah pola saluran tingkat 0 yaitu dari produsen ke konsumen.

\section{SARAN}

Usaha pengolahan terasi udang rebon masih berada pada skala subsisten, sehingga diperlukan peran berbagai pihak untuk mendukung pengembangan usaha ini berupa peningkatan skala produksi dan skala usaha. Peran yang dibutuhkan dalam usaha ini adalah 1) peningkatan kinerja pemasaran terasi udang keluar Kota Bontang, sehingga mampu mengantisipasi terjadinya kelebihan produksi pada bulan-bulan tertentu, 2) pengadaan bantuan fasilitas penjemuran terasi yang mampu diaplikasikan pada musim hujan, dengan tetap mempertahankan mutu terasi yang telah disukai oleh konsumen. Bantuan fasilitas ini bisa bersumber dari anggaran pembangunan dari pemerintah, atau dari dana pemberdayaan masyarakat oleh perusahaan yang ada di Kota Bontang, 3) bimbingan pembentukan kelompok pengolah terasi oleh pemerintah daerah melalui instansi teknisnya yaitu Dinas Kelautan dan Perikanan Kota Bontang.

\section{DAFTAR PUSTAKA}

Aristyan, Ibrahim, R., \& Rianingsih, L. (2014). Pengaruh perbedaan kadar garam terhadap mutu organoleptik dan mikrobiologis terasi rebon (Acetes sp.). Jurnal Pengolahan dan Bioteknologi Hasil Perikanan, 3, 60-66, 2014.
Badan Pusat Statistik. (2018). Kota bontang dalam angka. Bontang: Badan Pusat Statistik.

Crini, G., \& Badot, P. M. (2008). Application of chitosan, a natural aminopolysaccharide, for dye removal from aqueous solutions by adsorption processes using batch studies: A review of recent literature. Progress in polymer science, 33(4), 399447.

Dharma, S., Safrida, E., \& Sebayang, R. (2020). Rancang Bangun Mesin Giling dan Cetak Terasi, Pendampingan Manajemen dan Pemasaran. Jurnal Penelitian dan Pengabdian Kepada Masyarakat UNSIQ, 7(1), 11-15.

Djamin, Z. (1992). Perencanaan dan analisis proyek. Fakultas Ekonomi Universitas Indonesia. Jakarta.

Fauzi, S.., Iskandar, B.H.., Murdiyanto, B., \& Wiyono, E.S. (2011). Kelayakan finansial usaha perikanan tangkap di Selat Bali. Jurnal Teknologi Perikanan dan Kelautan, 1(2), 37-46

Gaffar, A., Umami, S. S., \& Supardan, D. (2020). Bacterial pollution of a traditional terasi, shrimp paste rebon (Mysis relicta). In 2nd International Conference on Islam, Science and Technology (ICONIST 2019) (pp. 142-146). Atlantis Press.

Gigentika, S., Wisudo, S.H., \& Mustaruddin. (2013). Kelayakan finansial usaha perikanan pancing tonda di PPP Labuhan Lombok Kabupaten Lombok Timur. Buletin IImiah PSP, 21(2).

Gray, C.S., Payaman, K.S., Lien, P.F.L., Maspaitela, \& Varley, R.C.G. (2002). Pengantar evaluasi proyek.. Jakarta: Gramedia Pustaka Utama.

Halim, A. (2011). Analisis investasi edisi kedua. Jakarta: Salemba Empat.

He, C., Lin, H., Dai, L., Qiu, R., Tang, Y., Wang, Y., ... \& Ok, Y. S. (2020). Waste shrimp, shellderived hydrochar as an emergent material for methyl orange removal in aqueous solutions. Environment international, 134, 105-340.

Jumingan. (2006). Analisis laporan keuangan. Jakarta: Bumi Aksara. 
Kadariah, L. (2001). Evaluasi proyek analisis ekonomi. Fakultas Ekonomi Universitas Indonesia. Jakarta.

Kandra, P., Challa, M. M., \& Jyothi, H. K. P. (2012). Efficient use of shrimp waste: present and future trends. Applied Microbiology and Biotechnology, 93(1), 17-29.

Kannan, S., Gariepy, Y., \& Raghavan, G. V. (2017). Optimization and characterization of hydrochar derived from shrimp waste. Energy \& Fuels, 31(4), 4068-4077.

Liang, X., Fan, X., Li, R., Li, S., Shen, S., \& Hu, D. (2018). Efficient removal of $\mathrm{Cr}$ (VI) from water by quaternized chitin/branched polyethylenimine biosorbent with hierarchical pore structure. Bioresource technology, 250, 178-184.

Musthofa, Z., \& Ainiyah, R. (2018). Analisis usaha terasi udang di Desa Tambaklekok Kabupaten Pasuruan. Jurnal Teknologi Pangan, 9(2), 123-131.

Nugraha, A. (2017). Analisis kelayakan finansial usaha terasi sijuk di Desa Sungai Padang Kecamatan Sijuk Kabupaten Belitung. repository ugm.ac.id
Rahmayati, Riyadi, P. H., \& Rianingsih, L. (2014). Perbedaan konsentrasi garam terhadap pembentukan warna terasi udang rebon (Acetes SP.) basah, Jurnal Pengolahan dan Bioteknologi Hasil Perikanan, 3, 108117.

Sugiyono. (2015). Metode penelitian kombinasi (mixed methods). Bandung: Alfabeta

Swastawati, F., Wijayanti, I, \& Susanto, E . (2008). Utilization of shrimp waste into edible coatingto reduce environmental pollution. Researchgate, 4, 101-106.

Syafril, M., Juliani, Susilo, H., \& Purnamasari, E. (2016). Skema Permodalan dan Pola Kemitraan Untuk Usaha Perikanan Rakyat. Samarinda: Mulawarman Universitas Press.

Tang, H., Zhou, W., \& Zhang, L. (2012). Adsorption isotherms and kinetics studies of malachite green on chitin hydrogels. Journal of hazardous materials, 209, 218225. 